\title{
Leadership
}

\section{The bright and dark sides of leadership: Transformational vs. non-transformational leadership in a non-Western context}

Leadership

9(I) 107-133

(C) The Author(s) 2013

Reprints and permissions: sagepub.co.uk/journalsPermissions.nav DOI: 10.1।77/17427/5012455131 lea.sagepub.com

\section{Zahide Karakitapoğlu-Aygün}

Faculty of Business Administration, Bilkent University, Turkey

\section{Lale Gumusluoglu}

Faculty of Business Administration, Bilkent University, Turkey

\begin{abstract}
The present study aims to explore positive and negative leadership behaviours (i.e. transformational and non-transformational leadership) in a non-Western 'change and transformation' context through qualitative methods. Thirty-one semi-structured interviews were conducted with knowledge workers in Turkey. In addition to the original dimensions found in the literature, four categories of transformational leadership emerged: benevolent paternalism, implementation of the vision, employee participation and teamwork, and proactive behaviour. Among these categories, benevolent paternalism was identified to be the most frequently mentioned aspect of transformational leadership in the Turkish context, which implies that cultural context may influence the form and enactment of transformational leadership. Regarding non-transformational leadership, five categories emerged: destructive, closed, passive/ineffective, active-failed and a miscellaneous category. Among these, destructive leadership that includes authoritarian elements was identified as the most frequently mentioned form of non-transformational leadership. These findings imply that non-transformational leadership comes in many forms, supporting the numerous constructs on the destructive/unethical-ineffective/incompetent continuum found in the negative leadership literature. The findings are discussed with reference to the literature and to social change in Turkey.
\end{abstract}

\section{Keywords}

Transformational leadership, non-transformational leadership, qualitative study, Turkey, knowledge workers 


\section{Introduction}

Researchers in the management literature proposed new models of leadership which are particularly suited to a 'change and transformation' context. Among those, Bass and Avolio's (1995) transformational leadership (TL) has especially attracted much attention in terms of its positive job outcomes (Bass 1990, 1995, 1998; Bass and Riggio, 2006). Numerous studies have found that transformational leaders enhance follower and organizational performance by articulating a compelling vision, by inspiring and intellectually stimulating their followers, and by building individualized relationships. During times of change and uncertainty, organizational members may become more receptive to such leaders since those behaviours of the leaders alleviate follower concerns and generate confidence. That is, assuredness, confidence and vision of the leader is a source of psychological comfort for the followers, where the leader shows how uncertainty can be turned into a vision of opportunity and success (Bass, 1985). As argued by Podsakoff et al. (1990), the trust, respect, vision and high performance expectations engendered by such charismatic leaders motivate followers to put forth effort beyond expectations, and to accept organizational change. In line with these observations, the present study, first, aims to provide a better understanding of TL by studying it through a qualitative methodology in a non-Western cultural context, i.e. Turkey, which is characterized by both social and economic change. As argued by Den Hartog and his colleagues (1999), although TL is universally endorsed, several of its attributes were perceived as culturally contingent and thus could be better studied by qualitative research. Accordingly, the present study takes a cultural and qualitative approach and explores the qualifications of transformational leaders who have actually transformed or can transform their followers and units or organizations. In line with the above-mentioned literature, TL is considered as a positive leadership style representing the bright side of leadership in a 'change and transformation context'. The organizational change context that is of interest to this study necessitates leaders who are successful in helping followers transcend their self-interest for the sake of the organization, pointing to this bright side of leadership.

In contrast to the above-mentioned positive image of leadership, a recent growing body of research is interested in the dark side of leadership, which is actually a reflection of a broader critical thinking movement in organizational sciences (Griffin and O'Leary-Kelly, 2004), where scholars have studied injustice, political behaviour, aggression, unethical behaviour, etc. This area of leadership includes topics such as destructive leadership (Schaubroeck et al., 2007), negative leadership (Schilling, 2009), abusive supervision (Tepper, 2000, 2007), workplace bullying (Ferris et al., 2007; Soylu, 2011) and toxic leadership (Frost, 2004; Padilla et al., 2007). Such research, referring to a continuum from ineffective/incompetent to destructive/unethical (Kellerman, 2004; Schilling, 2009), frequently found that destructive or negative leadership prevents followers and organizations from achieving goals. However, none of these studies specifically examined negative leadership in a change and transformation context. Indeed, leaders who are not capable of transforming their followers and organizations can lead to the downfall of their organizations, which is more likely to happen in periods when change is needed. At those times, leaders may act in unethical, tyrannical, despotic or inauthentic ways, abusing their power. They may show these kinds of behaviours either for the sake of organizational effectiveness or for their own personal interests, which may undermine followers' well-being (Einarsen et al., 2007; Liu et al., in press). To this end, the present study is interested in non-transformational leadership (nonTL) as a negative leadership construct representing the dark side of leadership in 'a change 
and transformation context'. It defines the non-transformational leader as one who cannot or does not transform his or her followers and units or organizations. More specifically, our second aim is to explore the content/domains of non-TL and to what extent they are representative of the above-mentioned continuum. Hereby, we use non-TL as an umbrella term for the dark side of leadership, as this negative leadership might include different leadership styles. In the section below, literature on TL and the dark side of leadership will be discussed.

\section{Transformational leadership}

Transformational leadership, developed by Bass and Avolio (1995) through a Multi-Factor Leadership Model (MLQ), has four components: idealized influence, individualized consideration, inspirational motivation and intellectual stimulation. By idealized influence, the leader instills admiration, respect and loyalty, and emphasizes the importance of having a collective sense of mission. By individualized consideration, the leader builds a one-to-one relationship with his or her followers and understands and considers their differing needs, skills and aspirations. Thus, transformational leaders meet the emotional needs of each employee (Bass, 1990). By inspirational motivation, the leader articulates an exciting vision of the future, shows followers ways to achieve the goals, and expresses his or her belief that they can do it. By intellectual stimulation, the leader broadens and elevates the interests of his or her employees, and stimulates followers to think about old problems in new ways. The leader who exhibits these behaviours not only helps followers to transcend self-interests for the sake of the organization, but also to exceed their initial performance expectations based on the strong emotional attachment she or he builds with them (Bass, 1995). As such, TL among other approaches, has been found to have positive associations with numerous outcomes, including employee commitment, job satisfaction, motivation and innovative behaviour (Lowe et al., 1996).

While these studies have certainly contributed to the understanding of TL, they are all based on the TL theory, which originated in the West. In practice, attributes that are seen as characteristic of effective leaders might vary in different cultures. In other words, followers may attach different meanings to a given leader's behaviour depending on the cultural context. Yet, the results of the GLOBE study showed that, while numerous features of TL are universally valid, TL attributes are not enacted in exactly the same manner across cultures (Den Hartog et al., 1999). For example, in high power-distance cultures such as Japan and China, a leader must be strong and authoritarian to be perceived as effective. In low power-distance cultures such as Australia and the Netherlands, an effective leader is egalitarian, participative and appears to be 'one of the boys' (Den Hartog et al., 1999). Showing individualized concern for subordinates' well-being and that of their family is desirable in cultures in the Middle East, Asia and Latin America, whereas such interest might be perceived as an invasion of privacy in a Western context. Based on these observations, this study aims to understand the meaning and attributes of TL in the non-Western context of Turkey.

The traditional business context in Turkey has been defined as relatively collectivistic and high in power distance (Aycan et al., 2000). Congruent with these cultural values, paternalism is a prevalent management style in the Turkish context (Berkman and Özen, 2007). In the literature, paternalistic leadership has been defined as a style that combines discipline, authority and power with fatherly benevolence, which implies that a leader demonstrates individualized holistic concern for subordinates' personal and familial well-being 
(Cheng et al., 2004; Farh and Cheng, 2000). Accordingly, in the Turkish context, employees tend to form and maintain close relationships with their leaders as well as avoid conflict with them. Leaders are expected to support, care and protect, and followers are expected to be loyal and compliant in return. Employees expect their superiors to act like a father figure and show concern for their personal and family-related problems. However, Turkey has been undergoing rapid social and economic change. Especially since the 1980s, people from the more progressive segments of society have shown more individualism in their values, but without a significant decline in relatedness (Imamoğlu and Karakitapoğlu-Aygün, 2004; Karakitapoğlu-Aygün, 2004). Accordingly, close relationships between leaders and followers and paternalistic features of leaders are still expected to be prevalent in the Turkish business context.

This social change has paralleled the economic change and liberalization efforts since the 1980s, which have helped to develop a private sector of small and medium-sized businesses. In 2001, a new programme for restructuring the economy and achieving long-term stability was designed. The newly introduced reforms and structural changes resulted in a remarkable economic recovery. In 2005, Turkey started European Union (EU) accession negotiations and began to align with the EU's legal order. In order to cope with competitive pressure from and market forces within the EU, major transformations have been occurring in all areas. Hence, candidacy to the EU has served as a significant driver of change for Turkish institutions and organizations. Consequently, it is very interesting to study how leaders act in a context characterized by social and economic change, which is a major aim of the present study.

\section{The dark side of leadership}

As mentioned above, the traditional stream of leadership research has focused on positive behaviours such as inspiring others, providing individualized support and serving as a role model. Only recently have studies started to investigate negative and dysfunctional traits and behaviours of leaders. One line of such research mainly studied abusive supervision which refers to 'subordinates' perceptions of the extent to which superiors engage in the sustained display of hostile verbal and nonverbal behaviours, excluding physical contact' (Tepper, 2000, p. 178). Such abusive leaders are mainly authoritarian and achieve obedience and submission by commanding, ridiculing, yelling at, lying to or humiliating, all of which result in perceptions of hostility among their followers. These behaviours call to mind personalized power-oriented leadership (McClelland and Burnham, 2003). Such leaders tend to be egoistic and emphasize their personal goals at the expense of the organization and their followers. They foster identification with themselves, but not with the vision and the goals of the organization. These unethical leaders tend to control rather than empower their followers.

More recently, Einarsen et al. (2007) proposed a conceptual model of destructive leadership, defining it as undermining organizational goals and effectiveness as well as the motivation and well-being of employees. Accordingly, they came up with three destructive leadership types: tyrannical, derailed and supportive-disloyal. Derailed leadership is the most damaging leadership style; it prevents both organizational and follower effectiveness. Tyrannical leadership includes anti-subordinate behaviours to achieve organizational goals. Finally, supportive-disloyal leadership involves considering the welfare of subordinates but violating the legitimate interests of the organization. In a similar vein, in a qualitative 
empirical research, Schilling (2009) identified different behavioural categories of negative leadership. His categories of insincere, despotic, exploitative and restrictive leadership, which represent task-oriented destructive behaviours, seem to resemble the behaviours in Einarsen et al.'s (2007) tyrannical leadership category. An avoiding leadership style, mostly representative of follower- and task-oriented behaviours, is more akin to the supportivedisloyal leadership category of Einarsen et al. (2007) and Aasland et al. (2010). Such leaders try to popularize themselves by setting low goals and do not account for certain decisions and actions. Finally, failed leadership, which is not easily located in Einarsen et al.'s model, includes active intervention in the daily business of subordinates while ignoring strategic tasks.

Based on these studies, it is possible to place negative leadership behaviours on a continuum ranging from ineffective/incompetent to destructive/unethical (Kellerman, 2004; Padilla et al., 2007). The destructive/unethical pole of this continuum can include behaviours such as intimidation, manipulation, coercion and one-way communication, rather than persuasion, influence and commitment (Conger and Kanungo, 1998; Howell and Avolio, 1992; Padilla et al., 2007). In line with their selfish orientation, such destructive leaders typically use impression-management and self-promotion and are more concerned with building support for themselves. The ineffective/incompetent pole, on the other hand, typically involves avoiding passive leadership style (Schilling, 2009) and laissez-faire leadership, with its low concern for tasks and followers (Einarsen et al., 2007; Schilling, 2009). As claimed by Padilla et al. (2007), although unethical/destructive actions (e.g. tactical bullying) are obviously negative, it is more difficult to claim that behaviours representing the ineffective/incompetent pole (e.g. disregarding the views of others, not motivating employees, communicating insufficiently) are equally so.

The present study aims to identify the aspects of non-TL and to what extent these dimensions are similar or different to the constructs defined in the negative leadership research. Luthans et al. (1998) proposed that destructive and negative leaders are more likely to emerge in cultures that are characterized by high uncertainty avoidance, collectivism and power distance, as Turkey is. For example, in such cultural contexts, followers are more tolerant of the power differentials that characterize tyranny and authoritarianism. One may ask, therefore, 'Are non-transformational leaders those who exert coercive power, and abuse and exploit their followers?' Or, 'Are non-transformational leaders those who avoid taking responsibility and who fully delegate tasks to employees?' This inquiry arises from the many studies on leadership in Turkey that have shown that a passive style of leadership is not desirable; employees expect their leaders to take charge, be in control and use a hands-on approach to problems (Paşa et al., 2001; Pellegrini and Scandura, 2006). Passive leadership, therefore, may emerge as a non-TL feature because it may not be possible for such leaders to take ownership of a change process or to persuade and motivate followers towards change. Based on these observations, we expect that the negative leadership continuum mentioned above may apply in the Turkish context as well.

The present study aims to contribute to the literature in two respects: 1) it will examine which leadership behaviours qualify as TL in organizations located in a developing country in transition from traditionalism to modernism, and 2) it will study which leadership behaviours qualify as non-TL; more specifically, which kind of ineffective/incompetent or destructive/unethical behaviours these leaders display during times of change. 


\section{Method}

\section{Selection of respondents}

Thirty-one semi-structured interviews were conducted with employees from different companies. This was the meaning saturation point, where no new information or themes were observed in the data (Gaskell, 2000). In order to acquire multiple perspectives (Strauss and Corbin, 1994), knowledge workers (10) and leaders (21) were interviewed. Five of the leaders were low-level, nine were mid-level and seven were senior managers. Furthermore, the heterogeneity of the sample was assured by choosing participants from different sectors (e.g. defence, banking, IT, academics, software, etc.), from the public and private sectors (14 and 17, respectively), and small and large organizations (7 and 24, respectively). Ten of the participants were female and 21 were male. The mean age was $38.7(\mathrm{SD}=5.46)$ and the average job and company tenures were 15.94 years $(\mathrm{SD}=5.27)$ and 8.52 years, $(\mathrm{SD}=7.40)$, respectively.

Our participants were highly qualified people with mostly academic backgrounds, many having master's and $\mathrm{PhD}$ degrees and coming from a variety of disciplines. The overall context where the participants work is characterized by a high degree of complexity and ambiguity. Many of our participants are drawn from Turkish companies which introduced change and innovations as well as restructuring to adapt to globalization in the last decade. As mentioned in the introduction, after the 1980s especially, as a result of the privatization and EU accession efforts as well as global competition, many of the companies included in this study have been going through major transformations to revitalize their organizations to respond to environmental pressures. In such times of uncertainty and crisis, leaders are under heavy pressure to act as 'transformational leaders' who have to take difficult decisions, as will be further discussed in the next section.

\section{Procedure}

Interviews were conducted by the two authors and their assistant in the participants' offices. All interviews were recorded on audiotape and the participants were ensured of confidentiality. On average, interviews lasted about an hour. At the beginning of the interview, respondents were given the definition of a transformational leader. In line with the original conceptualization of TL in the literature, transformational leaders were defined as those who transform their followers and units/organizations. Then, the respondents were asked to think about a specific leader from their own company or previous experiences whom they could use as a point of reference in answering the questions. They were instructed to think of a transformational leader who could or did transform his/her followers and units or organizations. Before we started with the questions, we wanted to make sure that respondents were thinking about a real transformation situation. Therefore, we asked them to describe the change story and the role of the leader in that change process in detail. All of the respondents referred to a transformation process where leaders played a critical role in changing their followers and units or organizations. Some of the transformation processes include changing the manual production system to full-automation and tripling the production in a very short period of time, transforming the first private university into world standards, moving from a production-oriented firm to an R\&D-oriented one, making a local truck and automotive company a global brand, transforming a public institution in the defence sector to be integrated with the international market and to introduce indigenous 
unique solutions to be competitive, transforming a local bank from a traditional deposittaking bank to an innovative, IT- and customer-oriented bank, transforming a public hospital unit to use and apply the principles of nanobiotechnology and nanomedicine, transforming a small technology company to one of the fastest growing and most innovative companies in the vehicle tracking and fleet management industry.

Following the funnel approach, the authors first asked general questions to generate unprompted spontaneous responses about the leader. Then, to capture all dimensions of TL, the authors continued with more specific questions: How did/does that leader behave towards followers? How did/does the leader motivate for change? How did/does the leader encourage innovation? How did/does the leader convince people to follow? How do/did followers feel about working with the leader?

Later, respondents were instructed to think of a non-transformational leader who could not or did not transform his/her followers and units or organizations. To maintain confidentiality, respondents were reminded not to identify the leader. Similar to the questions asked about TL, respondents were then asked to think about the behaviours and attributes of such non-transformational leaders, how they behave(d) towards their followers, how they respond(ed) to change and how the followers feel (felt) while working with such leaders.

Coding procedure: Transcripts of the interviews were divided into distinct 'thought units' (Trevino et al., 2003) by the two authors and their assistant separately. A thought unit or concept could be a word, phrase, sentence or multiple sentences, but each unit represented a distinct and separate thought about TL and non-TL behaviours. Units coded in different interviews, but which seemed synonymous, were collapsed. Then, taking categories from the theory as a starting point, different categories were developed (Schilling, 2006; 2007) and conceptually similar thought units were organized into those categories. For example, one interviewee said, 'transformational leaders plan the change well and prepare good action plans,' and another said, 'A transformational leader holds vision/crisis/information-sharing meetings.' Both comments were included in a category named 'implementation of the vision'. While developing the categories, the original dimensions of MLQ (Bass and Avolio, 1995) were maintained. To determine the reliability of the content analysis, a doctoral student trained in qualitative research techniques but unfamiliar with the study was asked to identify the emerging thought units. The authors found an inter-rater reliability of .80 after dividing the number of thought units which the raters agreed on by the total number of units. Furthermore, we identified the category reliability where we provided the items and definitions of the categories to the same student and asked them to place items under relevant categories. The category reliability was computed as .75. Then, the interviewees who mentioned each thought unit and how many times such thoughts appeared were each counted. As suggested by Hollensbe et al. (2008), a threshold of two people mentioning a behaviour was determined before recording that behaviour as a thought unit. This threshold is low enough to avoid including a phenomenon mentioned by a single respondent, but high enough not to exclude the emergence of a phenomenon shared by a couple of interviewees.

\section{Findings}

\section{Categories of transformational leadership}

Table 1 presents the categories and relevant thought units of TL. The authors identified eight categories, four of which are in line with the theoretical dimensions of TL in the literature (idealized influence, inspirational motivation, individualized consideration and intellectual 
Table I. Original and emergent categories of transformational leadership.

\begin{tabular}{|c|c|c|}
\hline Transformational leadership behaviors & $\begin{array}{l}\text { Number of } \\
\text { interviewees* }\end{array}$ & $\begin{array}{l}\text { Total number of } \\
\text { times mentioned** }\end{array}$ \\
\hline Inspirational motivation & & 253 \\
\hline Energizes others about goals to be achieved & 5 & 9 \\
\hline Appreciates and appraises success publicly & 7 & 21 \\
\hline Instils sense of responsibility and determination & 5 & 15 \\
\hline Gives tangible-intangible rewards & 19 & 95 \\
\hline Motivates employees for goal accomplishment & 19 & 58 \\
\hline $\begin{array}{l}\text { Ensures employees enjoy/are happy/feel satisfied about } \\
\text { their jobs }\end{array}$ & 14 & 40 \\
\hline Encourages employees to take ownership of their jobs & 8 & 15 \\
\hline Individualized consideration & & 210 \\
\hline Spends time teaching and coaching & 9 & 19 \\
\hline $\begin{array}{l}\text { Considers individuals as having unique needs, abilities and } \\
\text { aspirations }\end{array}$ & 4 & 14 \\
\hline $\begin{array}{l}\text { Helps employees develop themselves (by sending them on } \\
\text { training courses, to symposiums, conferences, etc.) }\end{array}$ & 16 & 54 \\
\hline $\begin{array}{l}\text { Presents success cases and helps employees meet with } \\
\text { successful people }\end{array}$ & 8 & 15 \\
\hline Develops future leaders & 4 & 7 \\
\hline Listens to and appreciates others' opinions and feedback & 17 & 56 \\
\hline Supports and stands by employees & 4 & 15 \\
\hline Knows the capabilities of employees & 5 & 20 \\
\hline Gives feedback to employees & 5 & 10 \\
\hline Idealized influence & & 188 \\
\hline Makes followers feel proud to be working with him or her & 5 & 14 \\
\hline $\begin{array}{l}\text { Considers the good of the organization/employees rather } \\
\text { than his or her own }\end{array}$ & 3 & 4 \\
\hline Acts in ways that build others' respect & 9 & 18 \\
\hline Builds trust and respect through his or her knowledge & 7 & 20 \\
\hline Builds trust and respect by keeping his or her promises & 5 & 14 \\
\hline Is a person with whom everyone wants to work & 2 & 6 \\
\hline Evaluates his or her employees' contributions fairly & 9 & 34 \\
\hline Earns the trust of employees & 17 & 68 \\
\hline Trusts his or her employees and shows it & 7 & 10 \\
\hline Intellectual stimulation & & 103 \\
\hline $\begin{array}{l}\text { Seeks different perspectives on and offers new ways of } \\
\text { solving problems }\end{array}$ & 2 & 2 \\
\hline Encourages/helps employees find solutions to problems & 3 & 8 \\
\hline $\begin{array}{l}\text { Creates an environment supportive of innovation and } \\
\text { creativity }\end{array}$ & 12 & 31 \\
\hline $\begin{array}{l}\text { Encourages employees to come up with new ideas and } \\
\text { projects }\end{array}$ & 13 & 29 \\
\hline $\begin{array}{l}\text { Promotes creativity by assigning new tasks and } \\
\text { responsibilities }\end{array}$ & 7 & 17 \\
\hline Gives importance to implementation of new ideas & 9 & 16 \\
\hline
\end{tabular}


Table I. Continued.

\begin{tabular}{|c|c|c|}
\hline Transformational leadership behaviors & $\begin{array}{l}\text { Number of } \\
\text { interviewees* }\end{array}$ & $\begin{array}{l}\text { Total number of } \\
\text { times mentioned** }\end{array}$ \\
\hline Benevolent paternalism & & 305 \\
\hline Behaves in a kind, but firm manner & 5 & 11 \\
\hline Builds close relationships, but keeps the power distance & 7 & 17 \\
\hline Asks for opinions, but makes own decisions & 2 & 2 \\
\hline Leads by example & II & 49 \\
\hline $\begin{array}{l}\text { Is concerned with employees' welfare and builds good } \\
\text { relationships with them }\end{array}$ & 19 & 80 \\
\hline Makes an effort to know employees intimately & 7 & 25 \\
\hline $\begin{array}{l}\text { Attends social events of employees and participates in their } \\
\text { special days }\end{array}$ & 19 & 62 \\
\hline Calls employees by name & 5 & 8 \\
\hline Is accessible/has an open-door policy & 12 & 31 \\
\hline Solves employees' problems & 4 & 20 \\
\hline Implementation of the vision & & 281 \\
\hline Sets challenging objectives & 4 & 5 \\
\hline Offers radical changes & 2 & 5 \\
\hline Holds vision/crisis/information-sharing meetings & 2 & 3 \\
\hline Has a vision and sets clear objectives & 10 & 19 \\
\hline $\begin{array}{l}\text { Takes initiatives to enter into foreign markets/different } \\
\text { sectors }\end{array}$ & 2 & 10 \\
\hline Plans the change well and prepares good action plans & 15 & 30 \\
\hline Believes in change, and then makes others believe in it & II & 22 \\
\hline $\begin{array}{l}\text { Makes people (top management, followers) believe in the } \\
\text { mission and objectives }\end{array}$ & 18 & 70 \\
\hline $\begin{array}{l}\text { Ensures that followers take ownership of mission/change/ } \\
\text { objective }\end{array}$ & 3 & 5 \\
\hline $\begin{array}{l}\text { Shares information, ideas, and reasons behind the decisions } \\
\text { with followers }\end{array}$ & 9 & 30 \\
\hline $\begin{array}{l}\text { Ensures followers understand the necessities and reasons } \\
\text { for change }\end{array}$ & 7 & 22 \\
\hline $\begin{array}{l}\text { Ensures followers understand the gains associated with } \\
\text { change }\end{array}$ & 5 & 12 \\
\hline Clearly expresses how to achieve objectives & 9 & 21 \\
\hline Communicates well what has been done in the company & 5 & 27 \\
\hline Employee participation and teamwork & & 201 \\
\hline $\begin{array}{l}\text { Appreciates and uses employees' knowledge and } \\
\text { experience }\end{array}$ & 5 & 16 \\
\hline Encourages initiative and delegates authority & 12 & 27 \\
\hline Facilitates employee participation in decision-making & 9 & 23 \\
\hline $\begin{array}{l}\text { Allows employees to participate in and contribute to } \\
\text { processes }\end{array}$ & 14 & 49 \\
\hline Forms his or her own team & 5 & 11 \\
\hline Gives the message of collective mission & 7 & 19 \\
\hline Stands by/supports his or her team & 6 & 22 \\
\hline
\end{tabular}


Table I. Continued.

\begin{tabular}{|c|c|c|}
\hline Transformational leadership behaviors & $\begin{array}{l}\text { Number of } \\
\text { interviewees* }\end{array}$ & $\begin{array}{l}\text { Total number of } \\
\text { times mentioned** }\end{array}$ \\
\hline $\begin{array}{l}\text { Doesn't blame employees in case of failure; shares } \\
\text { responsibility }\end{array}$ & 4 & 7 \\
\hline Works hard alongside team members & 8 & II \\
\hline Creates team spirit and improves collective efficacy & 6 & 8 \\
\hline Emphasizes that success belongs to the team & 3 & 8 \\
\hline Proactive behaviour & & 141 \\
\hline Fights/does not give up in the face of obstacles & 6 & 12 \\
\hline $\begin{array}{l}\text { Decreases tension and distress in the environment/calms } \\
\text { panic }\end{array}$ & 4 & 8 \\
\hline Removes obstacles in the way of progress & 2 & 4 \\
\hline Works fast and inspires employees to work fast & 8 & 24 \\
\hline Shows a hands-on approach in problem-solving & 5 & 16 \\
\hline Manages by walking around & 4 & 8 \\
\hline Follows up and finishes every task he or she starts & 11 & 29 \\
\hline $\begin{array}{l}\text { Uses his or her relationships/network for the benefits of } \\
\text { the organization }\end{array}$ & 3 & 13 \\
\hline Does not hesitate to make risky decisions & 4 & 12 \\
\hline Makes decisions quickly & 7 & 15 \\
\hline
\end{tabular}

Note: The first four categories refer to original dimensions of TL in the literature and the remaining four refer to the emergent categories found in the present study.

*Number of interviewees who referred to the item.

** The total number of times the item appeared in the data. For example, 5-9 means that the item was represented 9 times in 5 out of 31 interviews.

stimulation). The remaining four emergent categories were: benevolent paternalism, implementation of the vision, employee participation and teamwork and proactive behaviour. In the next sections, first, original categories of TL will be mentioned followed by emergent categories.

Original categories of transformational leadership. Inspirational motivation: As reported by the participants, transformational leaders energize their followers about goals and ensure that they enjoy and feel satisfied about their jobs using tangible and intangible tools to motivate their people. For example, transformational leaders recognize employees' successes in front of others. "When there is a new idea coming from an employee, this leader mentions it to the other managers and other personnel, emphasizing that it was that employee's idea. "Look, there is such an idea, I liked it a lot, and it came from this person." Of course, this makes an employee feel very proud.' Moreover, by conveying a sense of responsibility and determination, such leaders motivate employees to accomplish the company's goals: 'Whoever is doing that job is the owner of it. This makes you feel more responsible and you try to do better in your job.'

Individualized consideration: Transformational leaders acknowledge that employees have unique abilities and expectations, spend time teaching and coaching, help them develop themselves. 'He gives you whatever you need. He explains it very well... After a week or two, he realizes that you achieved five of the 10 things he explained. Then he starts to work on the remaining five. His plan is to take you from here to there. Where is that place? It is the place 
he thinks you will be most productive.' Transformational leaders are also aware of the capabilities of their employees and can determine which type of tasks they will be successful at. 'To be able to be a leader, you have to know your team well; what your team can do. You need to know their technical competence as well as what kind of people they are.' They not only stand by employees, but also take their opinions into account. They continuously give and take input and feedback.

Idealized influence: Transformational leaders instil feelings of pride, respect and trust among their followers. They earn that respect and trust with their knowledge, by keeping their promises or by behaving in a just manner. "If you promise, you keep it. You should not give promises you won't be able to keep." He used to live by this saying. He would not say, "We will do it" unless he was sure.' These leaders also demonstrate their trust in their employees. 'He would say, "You went to the field; you did the investigation. Of course I trust your judgment. Of course I approve of your decision." This is showing trust to the employee.' Leaders practising TL skills also subordinate their personal goals to company goals and consider the good of the organization and the employees above their own. For all these reasons, they are the leaders whom everyone wants to work with.

Intellectual stimulation: Leaders who are change-oriented tend to create an environment that is characterized by innovation and creativity. One of the leader participants defined the environment he created in the following way: "I ask my employees what they want from me. They want a device worth one hundred million dollars. "OK," I say, "I will give it to you next year. But you have to continue with that system and create your own project for me." I tell them that they have the system and they need to develop their own projects.' Transformational leaders strongly encourage the implementation of new ideas; therefore, they encourage employees to come up with new projects. For example, they try to promote creativity by assigning new tasks and responsibilities. Such leaders also stimulate employees to find their own solutions to problems. 'Sometimes we cannot solve a problem ... We talk and talk and he asks such questions that while answering them we suddenly find the solution we are looking for. He makes us find the solution ourselves.'

Emergent categories of transformational leadership. Benevolent paternalism: Transformational leaders are perceived as behaving respectfully, but firmly. These leaders do not refrain from showing their emotions, but are concerned about the good of their people. As indicated by one respondent about a leader: 'He built a kind, but firm relationship. He would get angry, but eventually, somehow, he would make it up to people. He was very suited to the Turkish leader type. Fathers get angry as well, but that fatherhood, love and respect never go away.' Consistent with this fatherly style, these leaders form close relationships with their followers, but they keep the power distance. 'This means that he should pat you on the back, but at the same time will stay a little bit distant . . because distance is important. It is this power distance that makes the charisma strong.'

Interviewees also mentioned that such leaders try to get to know each employee. These leaders are interested in all aspects of their employees' lives and thus participate in their special days (birthdays, weddings, funerals, etc.). 'On special days, say, somebody's birthday, he joins the party. Company picnics are organized. He attends them with his wife. He keeps the balance very well.' Another interviewee said, 'He never skips social activities: dinners, engagements, weddings. He definitely joins in and congratulates. Apart from that, he doesn't ignore important events like somebody buying a new car; he congratulates. These are not a burden for him. He keeps track of such days, and encourages other personnel to join in and be a part of 
such things.' Similarly, these leaders are expected to deal with the problems of their employees, again like a father does. They even try to solve the financial problems of their employees. 'One of our colleagues explained that many years ago, his father was very sick but due to lack of money, could not have surgery. One day, our leader learned about this and visited his father at their home. Then, he took him to the doctor and paid all the surgery expenses, but he asked the family not to disclose this information to anyone. Naturally, people are emotionally attached to a such leader.' And, 'One of our junior colleagues, who now has his own firm and makes good money, told us that his family was really poor in those days and that our leader paid all the expenses of his sister's wedding.'

Implementation of the Vision: Transformational leaders have vision and they set high objectives. To achieve their goals, they prepare good action plans. 'It is different to be able to write a scenario and edit it. I mean that deciding how we will proceed, what we will do next... is a different kind of intelligence.' These leaders believe in the vision first and then, encourage others to believe in it. As one interviewee said 'First, the person at the top of the business must believe in the change and this vision must spread from him. Otherwise, people don't believe in it.' To convince people, these leaders must communicate why change is necessary. Then, they must clearly express how to achieve the goals. That is, they must have a plan. 'It shouldn't just be a vague plan. It should be supported with some tools. Methods and procedures should be determined.' Followers should not only be convinced, but also motivated to follow that new direction. Showing followers the benefits they will receive if they succeed is an important tool. 'It should be communicated well that this change is necessary. There should be some goals. Knowing the things that will be gained if these goals are achieved motivates people better for the change.'

Employee participation and teamwork: Transformational leaders tend to create a participative environment that promotes feelings of belongingness. 'The first thing he said after hiring me was, "I have no experience in this area. Please share your experience with us. We are starting mass production and your experience is very important for us." That's incredible!' And 'He knows and remembers your opinions on an issue. For example, he calls you for a meeting unexpectedly. He says, "We have such a topic, you are experienced on this. You should participate." You are happy when you see that your contribution is appreciated.' Such leaders especially try to incorporate employees' ideas into the decision-making process. 'Decisions he made were usually collective decisions. Decisions were examined in detail, meetings were held; so they were mostly well-thought-out decisions.'

Such leaders are perceived to instil a team culture; they create a team spirit and enhance the collective efficacy of the members. 'The employees feel that their leader is strong. They look at other groups and believe that they are a stronger group. They think others cannot make it, but they can.' Transformational leaders are supportive and work hard with their team members. 'A leader is not someone who pushes team members, but acts with them, supports, encourages, energizes them and gives them different points of views.' Another respondent (who was a leader) said, 'On one project, we worked there night and day, Saturdays and Sundays, for about eight weeks. We worked together as a team and did a good job.' Consequently, team members of such leaders feel that regardless of whether there is success or failure in the end, it belongs to the team.

Proactive behaviour: According to the respondents, transformational leaders are expected to be action-oriented and assertive individuals with a hands-on approach. They are expected to remove obstacles and help followers through problems. They use a 'management by walking around' approach, which gives them opportunities to make positive comments 
and/or receive feedback. This approach generates high levels of spontaneous and creative synergy; for example, one interviewee said, 'In the morning, he tours through everybody and sits with his employees for a while. Starting with small talk, he brings the subject to what we have done, what we are doing and what we are going to do.' Such leaders are efficient and results-oriented, as evident in the following quote: 'He used to move very fast. He wanted everything to be finished fast. Since he was working fast, we were also finishing up jobs more quickly.' These leaders also do not hesitate to make risky decisions. 'Transformational leaders have incredible risk-taking potential. They may get reactions; their career may be negatively influenced. The risk might be big, but they take it.' Not only do they want to make things happen on time, but they also do not want to miss opportunities.

\section{Emergent categories of non-transformational leadership}

Table 2 presents the five emergent categories (and thus relevant thought units) of non-TL: destructive, closed, passive/ineffective, active-failed leadership and miscellaneous.

Table 2. Emergent categories of non-transformational leadership.

\begin{tabular}{|c|c|c|}
\hline Non-transformational leadership behaviours & $\begin{array}{l}\text { Number of } \\
\text { interviewees* }\end{array}$ & $\begin{array}{l}\text { Total number of } \\
\text { times mentioned** }\end{array}$ \\
\hline Destructive leadership & & 205 \\
\hline Is not candid & 3 & 7 \\
\hline $\begin{array}{l}\text { Does not explain things to employees; keeps } \\
\text { information to himself or herself }\end{array}$ & 2 & 4 \\
\hline Blames employees when things go wrong & 5 & 8 \\
\hline $\begin{array}{l}\text { Intimidates employees to make them work; is } \\
\text { aggressive, tough and intimidating; gets angry } \\
\text { quickly }\end{array}$ & 9 & 18 \\
\hline $\begin{array}{l}\text { Is disrespectful to employees; humiliates } \\
\text { employees }\end{array}$ & 10 & 21 \\
\hline Does not trust employees & 3 & 8 \\
\hline Demotivates employees & 5 & 9 \\
\hline Offends employees; makes them defensive & 3 & 4 \\
\hline $\begin{array}{l}\text { Is unconcerned about employees' careers; does } \\
\text { not let them improve themselves }\end{array}$ & 8 & 13 \\
\hline $\begin{array}{l}\text { Does not treat employees as individuals; treats } \\
\text { them as if they are replaceable }\end{array}$ & 2 & 4 \\
\hline $\begin{array}{l}\text { Emphasizes his or her interests more than inter- } \\
\text { ests of employees and the company; is not } \\
\text { committed to his or her job, team, or } \\
\text { employees }\end{array}$ & 5 & 7 \\
\hline Keeps employees under pressure & 5 & 9 \\
\hline $\begin{array}{l}\text { Prevents subordinates' contact/relations with } \\
\text { upper management }\end{array}$ & 5 & 8 \\
\hline
\end{tabular}


Table 2. Continued.

\begin{tabular}{|c|c|c|}
\hline Non-transformational leadership behaviours & $\begin{array}{l}\text { Number of } \\
\text { interviewees* }\end{array}$ & $\begin{array}{l}\text { Total number of } \\
\text { times mentioned** }\end{array}$ \\
\hline $\begin{array}{l}\text { Sees subordinates as a threat; fears losing his or } \\
\text { her position }\end{array}$ & 14 & 36 \\
\hline $\begin{array}{l}\text { Presents/sells employees'/team's success as his or } \\
\text { her own success }\end{array}$ & 8 & 21 \\
\hline $\begin{array}{l}\text { Creates an insecure and stressful work } \\
\text { environment }\end{array}$ & 5 & 8 \\
\hline $\begin{array}{l}\text { Does not/can not gain employees' trust, respect } \\
\text { or affection }\end{array}$ & 7 & 20 \\
\hline Closed leadership & & 173 \\
\hline Is not open to/is distrustful of change & 13 & 34 \\
\hline Is afraid of change and uncertainty & 6 & 10 \\
\hline $\begin{array}{l}\text { Is content with the current progress; does not } \\
\text { need change; likes status-quo }\end{array}$ & 16 & 44 \\
\hline Only accepts ideas that honour him/her & 2 & 3 \\
\hline $\begin{array}{l}\text { Maintains the system that hides his or her } \\
\text { weaknesses }\end{array}$ & 3 & 5 \\
\hline Does not spend time on change & 4 & 4 \\
\hline Is committed to hierarchy & 4 & 8 \\
\hline $\begin{array}{l}\text { Does not take new ideas seriously; is not inter- } \\
\text { ested in them }\end{array}$ & 7 & 18 \\
\hline $\begin{array}{l}\text { Is not open to applying new ideas; finds excuses } \\
\text { not to apply new ideas; tries to refuse new } \\
\text { ideas }\end{array}$ & 14 & 44 \\
\hline Hinders or hurts employees who seek change & 3 & 3 \\
\hline Passive/ineffective leadership & & 125 \\
\hline Avoids responsibility & 13 & 24 \\
\hline Does not take initiative & 3 & 8 \\
\hline Can not find solutions to problems & 2 & 2 \\
\hline $\begin{array}{l}\text { Does not make promises; does not keep his or } \\
\text { her promises }\end{array}$ & 2 & 3 \\
\hline $\begin{array}{l}\text { Hesitant to make decisions; extends decision- } \\
\text { making period; can not make decisions }\end{array}$ & 5 & 14 \\
\hline $\begin{array}{l}\text { Can not direct/advise employees; can not make } \\
\text { them believe in new ideas }\end{array}$ & 3 & 6 \\
\hline $\begin{array}{l}\text { Can not convince employees to take ownership } \\
\text { of the tasks }\end{array}$ & 4 & 9 \\
\hline $\begin{array}{l}\text { Does not care about teamwork; does not } \\
\text { appreciate team's/employees' successes }\end{array}$ & 5 & 6 \\
\hline $\begin{array}{l}\text { Can not clearly divide labour; can not clearly } \\
\text { explain his or her expectations }\end{array}$ & 4 & 13 \\
\hline $\begin{array}{l}\text { Can not maintain individualized relationships with } \\
\text { employees }\end{array}$ & 7 & 40 \\
\hline Active-failed leadership & & 114 \\
\hline Focuses mainly on mundane tasks & 2 & 3 \\
\hline Gets lost in details & 2 & 6 \\
\hline
\end{tabular}


Table 2. Continued.

\begin{tabular}{|c|c|c|}
\hline Non-transformational leadership behaviours & $\begin{array}{l}\text { Number of } \\
\text { interviewees* }\end{array}$ & $\begin{array}{l}\text { Total number of } \\
\text { times mentioned** }\end{array}$ \\
\hline $\begin{array}{l}\text { Only completes things that have low impact, that } \\
\text { fill time }\end{array}$ & 5 & 14 \\
\hline Controls everything employees do & 4 & 7 \\
\hline Interferes with everything employees do & 2 & 13 \\
\hline $\begin{array}{l}\text { Does things strictly in accordance with } \\
\text { specifications/procedures/rules }\end{array}$ & 5 & 11 \\
\hline $\begin{array}{l}\text { Only does what is assigned to him/her; does not } \\
\text { do anything extra }\end{array}$ & 2 & 5 \\
\hline Does not have a vision/strategy & 4 & 8 \\
\hline $\begin{array}{l}\text { Does not ask employees about their ideas; does } \\
\text { not include employees in decision-making } \\
\text { processes }\end{array}$ & 6 & 15 \\
\hline Does not encourage employee initiative & 5 & 14 \\
\hline $\begin{array}{l}\text { Talks too much; presents him- or herself very } \\
\text { well, but does not do much }\end{array}$ & 7 & 18 \\
\hline Miscellaneous & & 37 \\
\hline $\begin{array}{l}\text { Does not deserve his or her position; is there } \\
\text { through luck, politics, cyclical/coincidental } \\
\text { successes, etc. }\end{array}$ & II & 33 \\
\hline $\begin{array}{l}\text { Can not maintain the current situation; makes } \\
\text { it worse }\end{array}$ & 3 & 4 \\
\hline
\end{tabular}

*Number of interviewees who referred to the item.

** The total number of times the item appeared in the data. For example, 3-7 means that the item was represented 7 times in 3 out of 31 interviews.

Destructive leadership: Non-transformational leaders are perceived to be abusive, coercive, aggressive and intimidating, and use threats and fear for goal accomplishment, as indicated by the following quotes: 'They are very aggressive. They give orders and threaten people. People work hard not because they respect their leaders, but because they are scared. As such, when employees find an alternative, they quickly leave. They have no loyalty to such leaders.' And, 'They show their disrespect directly. They are disrespectful to you as a person, to your ideas, to your achievements. They don't listen. They even say to you directly, "You don't understand anything." And, 'These men like giving orders and await absolute loyalty. When things go wrong, they get very angry.' And, 'These leaders create an unhealthy climate. Employees become very unhappy, they start judging fairness at the workplace, they start gossiping. I know of so many people who had severe health problems due to such a negative atmosphere.'

Non-transformational leaders manipulate their followers to achieve their goals, as evident in the following quotes: 'When alone, he shows respect to you because he knows that you are technically superior to him. When in a group of others, he exhibits totally different behaviours. He ignores you. He uses the keywords he learned from you to gain respect from others. He sells what he learned from you.' And, 'He saw his employees as his competitors. That was why he always prevented their development.' And, 'They disrespect everyone. They see employees as unimportant. They are replaceable.' 
Non-transformational leaders are often afraid of losing their position and power; thus they prevent the development of their followers and perceive them as threats, as some of the participants experienced: 'He had no-self confidence. He liked the status quo and bureaucracy very much. He felt threatened when his employees achieved something. He was clearly blocking any communication between his employees and the upper levels.' And, 'All he did was protect his position by recruiting not-so-qualified candidates and by frustrating talented people.' Such non-transformational leaders generally have a selfish orientation and emphasize their interests more than those of their followers and their companies. They are not committed to their followers, tasks or their teams, as evident in the following quote: 'These men do not believe in teamwork. They have a high ego. They always say "I did it", "I succeeded".'

Destructive leaders are reported to be successful at impression management. To this end, they prevent follower contact with upper management and mostly present employees' and team's successes as their own. The next quotes exemplify these behaviours: 'Although he was the leader of our unit, he did not do much. Thus, informal leaders emerged and did their best to keep us tight. He was lucky. Without those informal leaders the company could have never survived. He survived because he communicated to the upper management as if it was his success.' And, 'He kindly asks for your ideas when alone. Then, he sells those ideas to upper levels as if they are his ideas. That was why we did not trust him; in fact we disliked him.'

Closed leadership: Non-transformational leaders are closed to new ideas and perspectives. They reject new proposals with a variety of excuses. They even try to sabotage change efforts, as exemplified in the following quotes: 'Some of our colleagues came up with new product ideas. He did not say no, but revised those projects in such a way that they were no more creative. Some of those products were produced in the way he wanted, but none of them sold in the market. They were no different than our existing products.' And, 'When people come up with innovative ideas, these leaders react in two ways. They either act politically and say, "Oh, this is a great idea. Let me think about it", but they do not give any feedback afterwards. Or else, they directly say, "Why do you waste your time on these things? Do only what is asked from you.",

Non-transformational leaders also can not tolerate uncertainty and can not take risks. 'When someone comes up with an idea, they immediately reject it. They do it by offering a counter project. Their tendency is to kill the ideas with opposing alternatives. They have no selfconfidence. How would someone with no self-confidence take risks?' And, 'He wanted to stay safe. He never took risks. He said we have to maintain our position and financial resources. He was even proud of not taking risks. He said, "See, we did not take any risks so we did not spend our resources." Such leaders only consider new ideas when they believe that these ideas will strengthen their power and position, as noted by one of the respondents: 'These leaders love their positions and power more than anything else. They would welcome anything that would make their position stronger. They would reject anything that would threaten their status.'

Passive/ineffective leadership: Non-transformational leaders are perceived to be ineffective because they can not convince their followers to take ownership of their tasks, make clear divisions of labour or set clear expectations. These leaders usually avoid responsibility and initiatives, as experienced by some respondents: 'He avoided responsibility, did not care how things were done or by whom they were done. He did not go out of his office.' Nontransformational leaders can not make decisions or find solutions to problems. 'We were going to purchase software. The software company came to us many times, made many presentations. He kept silent. Many of us tried to persuade him that we needed this product. He could not make a decision... In the end, we did not buy it; we continued with our existing manual system, which was really costly and burdensome.' And, 'He can not show his employees 
ways to solve their problems. When someone asks for help, he usually says, "Do it how you know." This way, he can never establish a standard way of doing things or solving problems.' Such leaders do not advise employees or maintain individualized relationships with their followers, as indicated by the following quotes: 'He did not have any emotional IQ. He could not build relationships with people, with employees, could not communicate with the customers.' And, 'They avoid communication with their employees. This is because when they communicate, they think they will have to confront problems. Also, they always have excuses not to attend company affairs.'

Active-failed leadership: Such leaders lack vision and mostly deal with operations that have low impact. 'They have no vision. They live for daily affairs. They have no objectives for the medium or the long-term.' And, 'I worked with such a leader for about five years. In spite of the changing customer profiles and technologies, he never changed his strategies. We told him that we were losing our customers and we had to change our strategies and sales methods. He did not listen.' These leaders also closely monitor their employees, interfering with everything they do and are therefore lost in details most of the time: 'He never trusted anyone. He micro-managed. He was controlling everything on a daily basis. He even kept his eyes on how much the company's drivers spent. Instead of delegating tasks to the HR manager, he himself kept all the details. That was why he could never think at the strategy level.' And, 'They talk too much. In fact, they do nothing... They like meetings very much, but they get nothing done.' And, 'He was controlling everything to death. For example, he was spending much time correcting typos and spelling in reports. He held frequent meetings to make sure everything was done in the way he wanted. What he said was the rule. We, as the R\&D team of nine people, left. Our project then failed. New people came but they could not elicit progress. The company lost millions of dollars.'

These leaders are also described as restrictive leaders (Schilling, 2009), such that they want to make sure that followers work according to the leader's rules and decisions, and they allow no freedom. As reiterated by respondents, 'These leaders keep saying, "I know what is best. I want this to happen. You should do it my way." They are committed to rules and procedures and force subordinates to follow the rules: 'Those leaders never take initiative because they think if they do, they will be in trouble. They want to be on the safe side. They follow the procedures tightly. They love bureaucracy.'

Miscellaneous: Non-transformational leaders are perceived to achieve success mostly through chance and politics. The respondents commented that such leaders do not deserve their positions because they did not achieve them through hard work and superior performance: 'That person was in that leadership position because of his father's contacts with the government. His first criterion at work was not to let anyone superior to him survive. He rejected any projects proposed by those who had the potential to challenge or threaten his position.' Such leaders are so ineffective that the company goes downhill: 'These leaders can not even maintain the current situation of the company. They make it worse. They destroy everything.' And, 'This leader could not institutionalize the organization. The company had earnings in the first years or so, but could not sustain them. Customers were no longer willing to do business with that company. Good days did not last long. Employees were frustrated. There were about 40 employees at that time. They left. Now there are only five of them.'

\section{Post hoc quantitative analyses}

We also conducted some quantitative analyses to test the extent to which the emergent categories of TL differed from the original dimensions of TL. For this purpose, we used 
the data collected in another study which is part of a larger project where our aim is to study the linkages between TL and innovation (Karakitapoğlu-Aygün and Gumusluoglu, 2012). A total of $230 \mathrm{R} \& \mathrm{D}$ employees participated in the study. The mean age of the sample was $29.15(\mathrm{SD}=4.7)$. The average job, company and leader tenures were $5.5(\mathrm{SD}=4.4), 3.9$ $(\mathrm{SD}=4)$ and 2.1 years $(\mathrm{SD}=2.1)$, respectively. TL was measured by 20 original items from Bass and Avolio (1995) and 22 of the items which emerged in the present study with the highest frequencies.

First of all, exploratory factor analysis with varimax rotation was conducted with the emergent category items. The analysis revealed that four emergent categories in the present study merged into two factors with an explained variance of $70.94 \%$. The first factor included Benevolent Paternalism, and Employee Participation and Teamwork items $(\alpha=.96)$. This factor was labelled as Paternalistic-Participative Leadership. The second factor included Proactive Behaviour, and Implementation of the Vision items $(\alpha=.95)$. This factor was named as Active-Charismatic Leadership. Furthermore, different models were proposed and tested by confirmatory factor analyses. Model 1 treated all of the original and emergent categories of TL as one factor $\left[X^{2}(819, \mathrm{~N}=230)=2840.60, X^{2} / d f=3.46\right.$, RMSEA $=.10, \mathrm{CFI}=.98]$. Model 2 treated Paternalistic-Participative Leadership and individualized consideration as the first, idealized influence and Active-Charismatic Leadership as the second, and intellectual stimulation and inspirational motivation as the third and fourth factors, respectively $\left[X^{2}(815, \mathrm{~N}=230)=2459.36, X^{2} / d f=3.02, \quad \mathrm{RMSEA}=.09\right.$, $\mathrm{CFI}=.98]$. Finally, Model 3 included six factors where the two emergent factors and the four original dimensions of TL were treated separately. The $X^{2}$ change results revealed that Model 3 (six-factor model) had the best fit $\left[X^{2}(813, \mathrm{~N}=230)=2440.74, X^{2} / d f=3.00\right.$, RMSEA $=.09, \mathrm{CFI}=.98$ ] and was statistically different from the other two models $(p<.001)$ suggesting that emergent and original categories differ and should be treated as different dimensions.

\section{Discussion}

The present study is among the first to explore the dimensions of TL and non-TL in a change and transformation context in a non-Western country by using a qualitative methodology. This study's TL-related results are consistent with Den Hartog et al. (1999), who reported that the TL concept is universally valid, but the behaviours of such leaders vary profoundly across cultures. Accordingly, the current results reveal that TL attributes in Turkey can be categorized into eight dimensions, of which four are in line with original TL dimensions (Bass and Avolio, 1995). The remaining four are emergent categories that are specific to change-oriented leaders in Turkey. Furthermore, the findings reveal five emergent categories of non-TL, most of which resemble the dimensions of negative leadership discussed in the literature, as will be explored below.

\section{Aspects of transformational leadership}

In line with the original dimensions of the MLQ (Bass and Avolio, 1995), change-oriented leaders in Turkey are perceived to be charismatic, to inspire and motivate their followers, to treat followers as unique individuals and to create an environment supportive of innovation and creativity. These dimensions of MLQ, namely, idealized influence, inspirational motivation, individualized consideration and intellectual stimulation, have been validated across 
cultures in many quantitative studies. The current qualitative study not only identified these dimensions as sub-domains of TL, but also showed that the meanings attributed to these domains were similar to the original conceptualizations. In fact, Den Hartog et al. (1999) pointed to such universally endorsed attributes of a transformational leader: he or she is encouraging, is positive, is forward-thinking, plans ahead, is motivating, builds confidence and is motivated. Since these sub-domains of TL are well established in the literature, the next section focuses only on the emergent categories from this study.

One emergent attribute of TL in the Turkish context was found to be benevolent paternalism. In line with the strong relationship- and power-distance orientation in Turkey, even transformational leaders are expected to act like father figures. Accordingly, these leaders were defined as individuals who attend the social and special days of employees, build close relationships but keep the power distance, and create a family-like atmosphere in the organization. Such a leader solves his employee's work problems as well as personal and family problems to show his care and nurturance like a father does. These results are consistent with the contention that paternalism is a prevalent leadership style in non-Western business settings (Aycan, 2006; Erben and Güneşer, 2008; Pellegrini and Scandura, 2006, 2008; Pellegrini et al., 2010; Soylu, 2011). In the Turkish context, where relationships between employees and supervisors are highly emphasized, knowledge workers want to form and maintain close and harmonious relationships with their leaders. One may note the similarity between individualized consideration (an original dimension of TL) and this study's benevolent paternalism category. As demonstrated, however, by Cheng et al. (2004), although the Western notion of individualized consideration and the Eastern notion of benevolent paternalism have some commonalities, there are also some differences between them. Accordingly, while individualized consideration includes leaders' care and support within the context of a task and is displayed in the context of equal treatment, benevolent paternalism involves dealing with subordinates' personal and family issues, is long-term oriented and implies a power differential between the leaders and the followers. Supporting these contentions, our findings revealed that the main theme in individualized consideration is helping employees develop themselves in task-related issues, whereas it is showing care and nurturance to enhance subordinates' personal and familial well-being in the case of benevolent paternalism. Further research is needed to test these results in different cultural contexts which differ in collectivism and power-distance dimensions. Moreover, future quantitative research should shed light on whether these two dimensions are distinct constructs, and represent etic and emic components of TL.

Another set of related attributes in this study is about the leaders' behaviours to implement their vision. In doing so, such leaders set challenging goals, offer radical changes such as entering new markets or sectors and plan the change well. They spend a considerable amount of time communicating their dreams and making owners, top management, followers and other stakeholders believe in the change, and to this end hold vision and informationsharing meetings with them. They try to convince followers to understand the benefits associated with the change and ensure that followers take ownership of it. Put differently, transformational leaders not only have a compelling vision and set clear long-term objectives, but they also come up with specific action plans and show how to achieve these objectives. Indeed, being a good executer and implementer was strongly emphasized as characteristic of transformational leaders by the interviewees. These findings are consistent with those of Paşa et al. (2001), who noted that 'such leaders behave and think in extremes ... they are ahead of others in recognizing what [the goals] should be and how to achieve them' (p. 582). This study's 
results are also supportive of Kirby et al. (1992: 309), who state that ' $[\mathrm{t}]$ he ordinary behaviours of planning, organizing and clarifying are not assessed by [the] MLQ, but were important to followers' perceptions of an extraordinary leader'.

Another theme closely related to TL in the Turkish context is having a participative and collaborative orientation. Accordingly, transformational leaders are expected to instil a team culture in the organization, to take into account others' opinions, to include followers in the decision-making process and to create a sense of collective mission and team spirit. As parts of the GLOBE study, previous studies also explored the effectiveness of such team-oriented leadership in Turkey (Kabasakal and Bodur, 2002; Paşa et al., 2001). Indeed, the emergence of this category in the present study is not surprising, given that all of the respondents were working in teams. Participation, teamwork and knowledge sharing are especially important for this type of employee because they are expected to create new knowledge, innovate and achieve synergy in teams.

The final emerging category in this study was related to being proactive. Transformational leaders are expected to be action-oriented and assertive. For example, they persist in the face of obstacles, they show a hands-on approach to problem-solving and they manage employees by walking around. Such leaders are risk-takers and fast decision-makers. In short, as part of their transformational roles, they are decisive and actively champion for the success of their change project. As part of the GLOBE study, Paşa et al. (2001) identified this proactive dimension as an attribute of outstanding leadership in Turkey. The demand for proactivity may be a reaction against the traditional Turkish business context, which is characterized by centralization, slow decision-making and risk avoidance. In such a context, leaders who use a hands-on approach to problems and make fast and risky decisions are perceived as successful and change-oriented. Notably this proactivity dimension calls to mind Antonakis and House's (2002) instrumental leadership which has been defined as leader behaviours concerning the enactment of leader expert knowledge toward the fulfilment of organizational-level and follower task performance. It is especially similar to the 'follower work facilitation' dimension of instrumental leadership which facilitates follower performance directly. Such behaviours include providing feedback, removing obstacles for goal attainment and ensuring that followers have sufficient resources. Future studies should shed light on this potential link between instrumental leadership and proactive leader behaviours.

To sum up, implementation of the vision, teamwork, and participation and proactivity emerged as important domains of TL in the Turkish context. More importantly, benevolent paternalism was identified as the most frequently mentioned emerging component of TL. Overall, these findings imply that TL is a 'variform universal' construct that holds across cultures, but the enactment of it varies between cultures (Den Hartog et al., 1999: 231). Interestingly, these findings also show that change-oriented leaders are expected to be visionary, future-oriented and intellectually stimulating on the one hand, and paternalistic on the other. This seemingly paradoxical concept of leadership may reflect the dual set of values in the Turkish context, which embodies 'the duality between east and west, tradition and modernity, religious and secular' (Kabasakal and Bodur, 2002: 51). The desire for benevolent paternalistic leadership is very strong in Turkey, yet there is also the desire for visionary, change-oriented leadership. Supporting these views, Sümer (2000) noted that paternalistic leaders in Turkey feel the pressure of keeping the company ahead of the game by using Western human resources practices and at the same time showing consideration for the personal and professional welfare of their employees. 


\section{Aspects of non-transformational leadership}

This study's results concerning non-TL yielded five emergent categories: destructive, closed, passive/ineffective, active-failed and a miscellaneous category. Among these categories, the most frequently mentioned and the most unethical one was destructive leadership, which includes authoritarian behaviours. Indeed, this dimension is similar to many destructive styles mentioned in the literature: abusive supervision (Tepper, 2000, 2007); despotic, exploitative and insincere leadership (Schilling, 2009); derailed leadership (Einarsen et al., 2007); strategic bullying (Ferris et al., 2007); and toxic leadership (Frost, 2004). As underscored by our respondents, destructive leaders emphasize their own interests more than those of their followers and their organization. Such leaders exhibit direct hostility towards their followers by showing abusive, coercive and intimidating behaviours. For example, they intimidate their employees to make them work, and are aggressive, tough, disrespectful and humiliating. They may also show indirect forms of hostility such as keeping information to themselves, not explaining things to employees, selling employees' successes as their own, etc. They perceive their followers as threats, prevent their development and contact with upper management, and blame them in times of failure. The emergence of such a destructive leadership style even in a knowledge worker context suggests that this dimension of leadership may be the most prototypical aspect representing the dark side of leadership in Turkey. It should also be noted here that destructive leadership in the literature is suggested to include behaviours in two domains: behaviours directed towards subordinates and behaviours directed towards the organization (Einarsen et al., 2007). The findings of the current study imply that destructive leaders who are described as non-transformational are those who undermine the organization's goals and effectiveness as well as the motivation and wellbeing of subordinates.

Another domain associated with non-TL is being closed to new ideas and change. Such leaders reject new ideas and proposals with a variety of excuses. Since they do not take risks, they either immediately reject the idea by citing financial and/or procedural constraints, or they continually delay giving feedback. Their main concern is to maintain their position in the company and thus they do not consider anything that might threaten that. It is possible that this dimension of non-TL is specific to leaders of knowledge workers; previous research on negative leadership does not often refer to this aspect. Unsurprisingly, this kind of leadership style is perceived especially negatively by knowledge workers due to the dynamic and creative nature of their work. In order to compete and survive in the knowledge era, R\&D workers and their leaders should be adaptive, dynamic and open to new ideas. Such features are extremely valuable in a context that is characterized by social and economic change. Leaders who are closed and anxious to maintain their status and position are much more likely to provoke negative reactions among their followers.

Active-failed leadership, another category of non-TL, includes leadership styles from previous research. As being similar to the restrictive leadership dimension of Schilling (2009), non-transformational leaders in this study were described as bureaucratic and procedural. They were committed to rules and procedures, and forced subordinates to follow the rules, allowing no autonomy. Failed leadership (Schilling, 2009) is another style included in this category. These leaders involve themselves too much in operational work, ignoring strategic decisions that need to be made. Rather than working from a strategy and a vision, such leaders focus on day-to-day operations, which have little impact on a company's overall performance. Since this active-failed domain includes the above-mentioned styles of failed 
and restrictive leadership from the previous literature, more research is needed to shed light on whether this dimension is universal or not.

In addition to the categories mentioned above, supporting the ineffective/incompetent pole of the negative leadership continuum (Kellerman, 2004; Padilla et al., 2007; Schilling, 2009), this study identifies a passive/ineffective leadership category. This dimension is similar to the passive-avoiding leadership style in Schilling's typology (2009). Accordingly, such leaders do not account for certain decisions, avoid responsibility, do not make promises, and do not keep their promises if they do make them. They are also perceived to be ineffective in the sense that they can not encourage followers to take ownership of their tasks, can not direct and guide their employees, can not make clear divisions of labour and can not set clear expectations. In terms of their relationships with their followers, they do not appreciate their employees' and teams' successes, do not care about teamwork and can not maintain individualized relationships with their employees. It should be noted that some of the items in this passive/ineffective category seem to resemble laissez-faire leadership (e.g. avoiding responsibility, not making decisions and not directing/advising employees). However, the major observation in this study is that the passive behaviour of a leader is not due to indifference (as is the case with a laissez-faire leader), but is due to incompetence. Hence, it is not surprising for knowledge workers to describe such leaders as non-transformational; guiding professional employees in the R\&D context requires compelling leadership skills in addition to technical expertise (Keller, 1992). Put differently, the soft skills of leadership, such as being decisive, risk-taking, proactive, persuasive and a team player, are critical in the effective management of knowledge workers.

If non-transformational leaders are ineffective and destructive, how do they get to such positions and remain there? This study's miscellaneous category reveals that such leaders do not deserve their positions. According to the respondents, these leaders usually achieve their positions through chance and politics (e.g. nepotism). As a matter of fact, in-group or informal recruitment is quite common in the Turkish work environment; screening and promotion decisions are often based on relationships rather than competence and performance factors (Aycan, 2001; Bradburn, 1963; Sümer, 2000; Wasti, 2002). The miscellaneous category also refers to some organization-related consequences of such negative leadership. As indicated by our respondents, these leaders can not maintain the company's current performance; after some time, things deteriorate. As noted by Padilla et al. (2007: 178), 'it is the long-term negative ramifications that prompt the "destructive" label' of such leadership styles. In line with this view, non-transformational leaders may be expected to harm their organizations in the long run, which may be a promising avenue for future research.

Future research might also examine the predictors of non-transformational leadership. As noted by Schilling (2009), follower-related antecedents, such as low motivation and a weak work ethic, as well as organizational/environmental factors such as high market competition and pressure, may set the foundation for negative leadership and consequently result in stress and perceived injustice among followers. Such situations may result in a 'trickle down phenomenon' (Schilling, 2009: 123), in which the leader-follower relationship weakens as the followers show less motivation and more negative affect, which thus intensifies the negative leadership behaviour. Supporting these claims, Tepper, Moss and Duffy (2011) showed that subordinates who are perceived to be lower performers become targets of abusive supervision. Future studies could examine the leadership issue from this interactional framework (Hughes et al., 2009). 


\section{Theoretical and practical implications}

This is the first study to shed light on non-transformational leadership behaviours. Although numerous previous studies have examined negative/destructive leadership, none of them has specifically studied negative leadership behaviours in a change context. By demonstrating a wide variety of negative leadership constructs on an ineffective/incompetent and destructive/ unethical continuum (Kellerman, 2004; Schilling, 2009), the current findings imply that negative leadership manifests itself in many forms. The prevalence of these domains, however, may vary across different contexts. For example, Aasland et al. (2010) illustrated that in Western contexts, passive forms of destructive leadership behaviours tend to be more prevalent than active ones. In contrast, active forms of negative leadership, namely destructive and active-failed styles emerged more frequently in the current study. Accordingly, nontransformational leaders were found to be active in managing low-value operational tasks and in exploiting, humiliating and abusing their followers. The high frequency of this active/ negative leadership as compared to passive/ineffective leadership might be attributed to the high power distance in Turkish workplaces, where leaders might not hesitate to explicitly show their aggression and abusive behaviour. Future research could shed a brighter light on the active-passive dimension of leadership while studying negative leadership in different cultural contexts.

In terms of TL-related findings, this is a pioneering study that identifies benevolent paternalistic leadership as an emergent attribute of TL in a collectivistic non-Western context. This finding contrasts with previous contentions that suggest paternalistic leadership and TL are two different constructs (Chen et al., in press). Hence, the findings of this study call for both qualitative and quantitative future research to revisit the TL construct, and explore and test whether this finding holds in different cultural contexts. In contrast to previous assumptions about the potential negative impact of paternalism in the US context, recent research has shown that paternalistic leadership is significantly and positively related to affective organizational commitment in US business organizations (Pellegrini et al., 2010). Based on these unexpected findings, Pellegrini et al. (2010) suggested that paternalistic leadership may generalize to individualistic cultures as well. Moreover, since the transformation of followers and organizations includes potential ambiguities, risks and costs, as well as anticipated benefits, the process may provoke the very human feelings of frustration, tension and fear of failure among the subordinates. Recognizing such feelings, transformational leaders with benevolent paternalistic leadership behaviours can address these concerns by nurturing, caring, supporting and building emotional ties with their followers, regardless of culture. The global economic crisis, restructuring of economies and organizations and increased downsizing may call for benevolent paternalistic management to cope with these transformations even in individualistic Western cultures.

This study's findings also contribute to the theoretical discussion in the literature on whether paternalism is a negative or positive attribute. First of all, the TL-related findings imply that showing care and concern for employee well-being and creating a family environment that is benevolent paternalism is conducive to the effective management of knowledge workers. Second, the non-TL-related findings imply that destructive leadership is more similar to the authoritarianism construct in the paternalism literature which includes controlling and exploiting the subordinates (Aycan, 2006). In Western contexts, paternalistic leadership has been mostly associated with authoritarianism, although the correlation between these two constructs is negative. As argued by Pellegrini and Scandura (2008: 570), '[t]he negative 
association between paternalism and authoritarianism indicates that once exploitation replaces benevolence, and control replaces concern, the relationship moves away from paternalism toward authoritarianism'. Supporting these contentions, the findings of this study illustrate that benevolent paternalism is positive and represents the bright side of leadership, while authoritarianism (e.g. the destructive leadership dimension of non-TL in this study) is negative and represents the dark side of leadership in the Turkish context.

This study is not without its limitations. It specifically examines change-oriented leadership from the perspective of knowledge workers. Knowledge workers have different characteristics, and a significant drive for achievement and personal growth compared to workers carrying out routine tasks (Drucker, 1999). Thus, the meaning attributed to negative leadership may be different among a traditional group of workers, which should be examined in future investigations. Moreover, the findings should be viewed especially cautiously due to the fact that the respondents are from a power-distant and collectivist country, and one that is in a transition period. Future research can capitalize on the findings by gathering data from other cultures to investigate the etic and emic dimensions of TL and non-TL. Furthermore, future quantitative studies are needed to test the construct validity of the dimensions identified in the study and provide statistical evidence how our emergent categories of TL and non-TL differentiate from original dimensions of TL and other negative leadership domains (e.g. Schilling, 2009) in the literature.

The findings have several implications for leaders of knowledge workers, and human resource managers of Turkish companies, and those of multinational companies who operate or plan to operate in Turkey. First of all, the study reveals interesting results regarding the importance of cultural influences on leadership. In line with the social and the economic transition in Turkey, transformational and change-oriented leaders are expected to change the system and challenge existing ways of doing things, yet also to be traditional and paternalistic. Leaders in Turkey should pay attention to these unique cultural expectations. Second, the findings on non-TL imply that HR managers should find and use effective procedures in the selection process to identify and screen out potentially negative and non-transformational leaders. Even in the promotion process, such leaders can be identified by measures such as feedback from subordinates and moral and ethical judgment ratings (Craig and Gustafson, 1998). Moreover, performance evaluations may include negative leadership behaviours and characteristics in addition to positive and desirable leadership qualities. It would be interesting to include dimensions of non-TL in leadership programmes to help leaders reflect on ineffective and unacceptable behaviours. The findings also imply that a heavy emphasis on ethical behaviour and judgment (Trevino et al., 2003) in management training and education is essential. As mentioned by Howell and Avolio (1992), enhancing ethical judgment and behaviour through policies and enforcement programmes may reduce destructive and abusive leader behaviours.

The findings of this study are significant because they draw attention to the bright and dark sides of leadership in a change and transformation context. The study encourages future inquiry into the behaviours of TL and non-TL in different cultural and organizational contexts facing the challenges of transformation.

\section{Funding}

This work was supported by the Scientific and Technological Research Council of Turkey (tubitak) [Grant number 107k439]. 


\section{References}

Aasland MS, Skogstad A, Notelaers G, Nielsen MB and Einarsen S (2010) The prevalence of destructive leadership behavior. British Journal of Management 21: 1467-8551.

Antonakis J and House RJ (2002) An analysis of the full-range leadership theory: The way forward. In: Avolio BJ and Yammarino FJ (eds) Transformational and Charismatic Leadership: The Road Ahead: 3-33. Amsterdam: JAI Press.

Aycan Z (2001) Human resource management in Turkey: Current issues and future challenges. International Journal of Manpower 22(3): 252-260.

Aycan Z (2006) Paternalism: Towards conceptual refinement and operationalization. In: Kim U, Yang K and Hwang KK (eds) Indigenous and Cultural Psychology: Understanding People in Context. New York: Springer, pp. 445-466.

Aycan Z, Kanungo RN, Mendonce M, Kaicheng Y and Deller J (2000) Impact of culture on human resource practices: A 10 country comparison. Applied Psychology: An International Review 49(1): 192-221.

Bass BM (1985) Leadership and Performance Beyond Expectations. New York: The Free Press.

Bass BM (1990) Bass and Stogdill's Handbook of Leadership: Theory, Research, and Managerial Applications. New York: The Free Press.

Bass BM (1995) Transformational Leadership. Journal of Management Inquiry 4(3): 293-298.

Bass BM (1998) Transformational Leadership: Industrial, Military and Educational Impact. London: Lawrence Erlbaum.

Bass BM and Avolio BJ (1995) MLQ: Multifactor Leadership Questionnaire, 2nd edn. Redwood City, CA: Mind Garden.

Bass BM and Riggio RE (2006) Transformational Leadership. Mahwah, NJ: Lawrence Erlbaum.

Berkman Ü and Özen Ş(2007) Turkish business system and managerial culture: State dependency and paternalism in transition. In: Davel E, Dupuis JP and Chanlat JF (eds) Culture and Management in the Contemporary World. Quebec: Laval University (CD-rom).

Bradburn NM (1963) Interpersonal relations within formal organizations in Turkey. Journal of Social Issues 31: 61-67.

Chen XP, Eberly MB, Chiang TJ, Farh JL and Cheng BS (in press) Affective trust in Chinese leaders: Linking paternalistic leadership to employee performance. Journal of Management.

Cheng B, Chou L, Wu T, Huang M and Farh J (2004) Paternalistic leadership and subordinate responses: Establishing a leadership model in Chinese organizations. Asian Journal of Social Psychology 7: 89-117.

Conger JA and Kanungo RN (1998) Charismatic Leadership in Organizations. London: Sage.

Craig SB and Gustafson SB (1998) Perceived leader integrity scale: An instrument for assessing employee perceptions of leader integrity. Leadership Quarterly 9: 127-145.

Den Hartog DN, House RJ, Hanges PJ, Ruiz-Quintanilla SA, Dorfman PW and GLOBE Associates (1999) Culture specific and cross-culturally generalizable implicit leadership theories: Are attributes of charismatic/transformational leadership universally endorsed? Leadership Quarterly 10(2): 219-256.

Drucker PF (1999) Knowledge-worker productivity: The biggest challenge. California Management Review 41: 79-94.

Erben GS and Güneşer AB (2008) The relationship between paternalistic leadership and organizational commitment: Investigating the role of climate regarding ethics. Journal of Business Ethics 82: 955-968.

Einarsen S, Aasland MS and Skogstad A (2007) Destructive leadership behaviour: A definition and conceptual model. Leadership Quarterly 18(3): 207-216.

Farh JL and Cheng BS (2000) A cultural analysis of paternalistic leadership in Chinese organizations. In: Li JT, Tsui AS and Weldon E (eds) Management and Organizations in the Chinese context. London: MacMillan, pp. 84-127. 
Ferris GR, Zinko R, Brouer RL, Buckley MR and Harvey MG (2007) Strategic bullying as a supplementary, balanced perspective on destructive leadership. Leadership Quarterly 18: 195-206.

Frost PJ (2004) Handling toxic emotions: New challenges for leaders and their organization. Organizational Dynamics 33: 111-127.

Gaskell G (2000) Individual and group interviewing. In: Bauer MW and Gaskell G (eds) Qualitative Researching: With Text, Image and Sound. London: Sage, pp. 38-56.

Griffin RW and O'Leary-Kelly AM (2004) The Dark Side of Organizational Behavior. San Francisco: Jossey-Bass.

Hollensbe EC, Khazanchi S and Masterson SS (2008) How do I assess if my supervisor and organization are fair? Identifying the rules underlying entity-based justice perceptions. Academy of Management 51(6): 1099-1116.

Howell JM and Avolio BJ (1992) The ethics of charismatic leadership: Submission or liberation? Academy of Management Executive 6: 43-54.

Hughes R, Ginnettt R and Curphy G (2009) Leadership: Enhancing the Lessons of Experience. McGraw-Hill.

Imamoğlu EO and Karakitapoğlu-Aygün Z (2004) Self-construals and values in different cultural and socioeconomic contexts. Genetic, Social and General Psychology Monographs 130(4): 277-306.

Kabasakal H and Bodur M (2002) Arabic Cluster: A bridge between East and West. Journal of World Business 37: 40-54.

Karakitapoğlu-Aygün Z (2004) Self, identity and emotional well-being among Turkish university students. The Journal of Psychology 138: 457-478.

Karakitapoğlu-Aygün Z and Gumusluoglu L (2012). A Re-Conceptualization of Transformational Leadership in the Turkish Context. Unpublished manuscript, Bilkent University, Ankara.

Keller RT (1992) Transformational leadership and the performance of research and development project groups. Journal of Management 18(3): 489-501.

Kellerman B (2004) Bad Leadership: What it Is, How it Happens, Why it Matters. Boston, MA: Harvard Business School Press.

Kirby PC, Paradise LV and King MI (1992) Extraordinary leaders in education: Understanding transformational leadership. Journal of Educational Research 85: 303-311.

Liu D, Liao H and Loi R (in press) The dark side of leadership: A three-level investigation of the cascading effect of abusive supervision on employee creativity. Academy of Management Journal.

Lowe KB, Kroeck GK and Sivasubramaniam N (1996) Effectiveness correlates of transformational and transactional leadership: A meta-analytic review of the MLQ literature. Leadership Quarterly 7(3): 385-425.

Luthans F, Peterson SJ and Ibrayeva E (1998) The potential for the 'dark side' of leadership in postcommunist countries. Journal of World Business 33: 185-201.

McClelland DC and Burnham DH (2003) Power is the great motivator. Harvard Business Review, Jan $117-126$.

Padilla A, Hogan R and Kaiser R (2007) The toxic triangle: Destructive leaders, susceptible followers and conducive environments. Leadership Quarterly 18: 176-194.

Paşa SF, Kabasakal H and Bodur M (2001) Society, organizations and leadership in Turkey. Applied Psychology: An International Review 50(4): 559-589.

Pellegrini EK and Scandura TA (2006) Leader-member exchange (LMX), paternalism and delegation in the Turkish business culture: An empirical investigation. Journal of International Business Studies 37: 264-279.

Pellegrini E and Scandura TA (2008) Paternalistic leadership: A review and agenda for future research. Journal of Management 4(3): 566-593.

Pellegrini EK, Scandura TA and Jayaraman V (2010) Cross-cultural generalizability of paternalistic leadership: An expansion of Leader-Member Exchange theory. Group \& Organization Management 35(4): 391-420. 
Podsakoff PM, MacKenzie SB, Moorman RH and Fetter R (1990) Transformational leader behaviors and their effects on followers' trust in leaders, satisfaction, and organizational citizenship behaviors. Leadership Quarterly 1: 107-142.

Schaubroeck J, Walumba FO, Ganster DC and Kepes S (2007) Destructive leader traits and neutralizing influence of an enriched job. Leadership Quarterly 18: 236-251.

Schilling J (2006) On the pragmatics of qualitative assessment: Designing the process for content analysis. European Journal of Psychological Assessment 22(1): 28-37.

Schilling J (2007) Leaders' romantic conceptions of the consequences of leadership. Applied Psychology: An International Review 56(4): 602-623.

Schilling J (2009) From ineffectiveness to destruction: A qualitative study on the meaning of negative leadership. Leadership 5: 102-128.

Soylu S (2011) Creating a family or loyalty-based framework: The effects of paternalistic leadership on workplace bullying. Journal of Business Ethics 99: 217-231.

Strauss A and Corbin J (1994) Grounded theory methodology. In: Denzin NK and Lincoln YS (eds) Handbook of Qualitative Research. Thousand Oaks, CA: Sage, pp. 273-285.

Sümer HC (2000) A historical and cultural approach to analyzing performance appraisal (in Turkish). In: Aycan Z (ed.) Management, Leadership and Human Resource Practices in Turkey. Ankara: Turkish Psychological Association, pp. 57-90.

Tepper BJ (2000) Consequences of abusive supervision. Academy of Management Journal 43: 178-190.

Tepper BJ (2007) Abusive supervision in work organizations: Review, synthesis and research agenda. Journal of Management 33: 261-289.

Tepper BJ, Moss SE and Duffy MK (2011) Predictors of abusive supervision: Supervisor perceptions of deep-level dissimilarity, relationship conflict, and subordinate performance. Journal of Management 54: 279-294.

Trevino LK, Brown M and Hartman LP (2003) A qualitative investigation of perceived executive ethical leadership: Perceptions from inside and outside the executive suite. Human Relations 56(1): 5-37.

Wasti A (2002) Affective and continuance commitment to the organization: Test of an integrated model in the Turkish context. International Journal of Intercultural Relations 26(5): 525-550.

\section{Author biographies}

Zahide Karakitapoğlu-Aygün is an Associate professor at Faculty of Business Administration at Bilkent University. She has a PhD in social psychology from Middle East Technical University, Turkey. Her research interests include commitment to multiple foci, transformational leadership, organizational justice, team innovation and team processes. She published in several journals such as Journal of Cross-Cultural Psychology, Journal of Business Ethics, European Journal of Social Psychology, Journal of Social Psychology and Journal of Business Research.

Lale Gumusluoglu received her $\mathrm{PhD}$ in Organization and Management from Hacettepe University, Turkey. She is a lecturer at Faculty of Business Administration at Bilkent University. She also serves at the Executive Boards of Anatolian Strategic Research Foundation, Technology Management Association and Innovation Association. Her research interests include leadership, knowledge workers, individual and team-level innovation \& creativity, commitment and justice. Her articles were published in journals such as Journal of Product Innovation Management, Journal of Business Research and International Journal of Market Research. 
